\title{
A REVIEW OF SAMPLING PROCEDURES AVAILABLE FOR IPM DECISION-MAKING OF FOREST AND SHADE TREE INSECTS IN NORTH AMERICA
}

\author{
By Christopher J. Fettig', Jeffrey G. Fidgen², and Scott M. Salom ${ }^{3}$
}

\begin{abstract}
Integrated Pest Management (IPM) programs attempt to reduce insect associated losses to acceptable levels using multiple techniques that are effective, economically viable, and ecologically compatible. Sampling is the cornerstone of any IPM program, and significant effort has been devoted to the development, theory, and application of sampling methods. Relatively few IPM programs exist for managing forest and shade tree pests despite the availability of sampling procedures that are potentially useful for control decision-making. The majority of these sampling procedures are published on defoliating insects (58\% of all publications). The most commonly referenced defoliators are the gypsy moth, Lymantria dispar (L.); Douglas-fir tussock moth, Orgyia pseudotsugata (McDunnough); spruce budworm,

Choristoneura fumiferana (Clemens); and western spruce budworm, C. occidentalis Freeman. These four species alone account for 35\% of all sampling publications relevant to IPM programs. The second largest group is bud, shoot, and root insects (16\%) followed closely by wood- and bark-boring insects (11\%). The piercing-sucking feeding group (10\%) and seed and cone insects (5\%) have relatively few sampling procedures available. Ninety-two percent of the species represented are predominately forest pests, with the order Lepidoptera and family Tortricidae most commonly reported. A significant opportunity exists for developing similar tools to aid in control decision-making for a large number of other pests. Current trends suggest that efforts should concentrate on species important to the urban forest and intensively managed forest plantations.
\end{abstract}

Key Words. Sampling techniques; sampling programs; sequential sampling; action thresholds; forest insects; shade tree insects; urban forestry.

The development of sampling programs for arthropod pests is an extensive area of research (Morris 1955; Strickland 1961; Southwood 1978; Coulson and Witter 1984; Billings 1988; Barbosa and Wagner 1989; Dent 1991; Kuno 1991; Binns and Nyrop 1992; Pedigo and Buntin 1994; Sidebottom 1995; Fettig et al. 2001) and consists of two distinct components: the sampling technique and sampling program (Pedigo 1989). An effective sampling technique, such as in situ counts or trapping, must first be developed to facilitate collection of data during each sample. The sampling program describes procedures for deploying the sampling technique temporally and spatially (Pedigo 1989,
1994). For example, a typical sampling program will define the sample unit, the appropriate insect stage to sample, the number of samples to be collected, the timing of each sample, and the pattern of sampling (i.e., random or systematic) (Southwood 1978; Pedigo 1989, 1994; Royama 1992; Fox et al. 1997). Today, decision support systems are commonly used to integrate sampling estimates, action thresholds, and geographical information systems into useful area-based platforms (Power et al. 2001).

Action or economic thresholds indicate when management actions should commence (Pedigo et al. 1986; Pedigo 1989) and can result in substantial reductions in insecticide use at a considerable cost savings (Coffelt and Schultz 1990; Dent 1991; Binns and Nyrop 1992; Fox et al. 1997). Thresholds are often based on relationships between pest density and host impacts (Raupp et al. 1992; Rieske and Raffa 1993; Liebhold et al. 1994), such as aesthetics (Buhyoff et al. 1982; Coffelt and Schultz 1990), loss of growth or vigor (Fox et al. 1997), and economics (Pedigo et al. 1986; Rawat et al. 1987; Fox et al. 1997).

Sequential and binomial sampling plans are extremely useful for decision-making purposes (Waters 1955; Binns and Nyrop 1992). In entomology, sequential sampling plans are based on dispersion patterns and action thresholds, which facilitate placement of populations into crude categories (e.g., endemic and epidemic) with an economy of samples. When pest populations are either very low or very high, sequential sampling plans require about half the effort of plans based on fixed sample sizes (Waters 1955; Fowler and Lynch 1987; Binns and Bostanian 1990; Brewer et al. 1994; Fettig et al. 2001). Binomial sampling programs relate a variable that is easy to measure, such as the proportion of sampling units that are infested, with one that is more difficult to obtain, such as absolute density (Waters 1955; Brewer et al. 1994; Nyrop and Binns 1992). Many variations of the two sampling plans exist (Fowler and Lynch 1987; Pedigo 1989, 1994; Legg et al. 1994; Fettig et al. 2001).

Much of the forest and shade tree sampling literature is difficult to find and interpret and is, therefore, inaccessible to most resource managers. In 2001, we compiled all sampling techniques on forest pests and developed an unambiguous, comprehensive database useful to resource 
managers, urban foresters, and arborists (Fettig et al. 2001). Papers were selected for the database based on the criterion that they reported a sampling technique or sampling program that was useful for IPM decision-making. This material is now also accessible at http://everest.ento.vt.edu/ $\sim$ salom/Samplemeth and is updated annually.

The following demographic is based on Fettig et al. 2001, which included 125 publications (entries) representing 55 species, 22 families, and 6 orders. Papers spanned more than 50 years of entomological research, but most entries were published within the past 30 years. Sampling summaries were available for $35 \%$ and $45 \%$ of forest pests considered at least moderately important in Canada and the United States, respectively (Armstrong and Ives 1995; USDA-FS 1998, 1999, 2000).

\section{RELATIVE ABUNDANCE OF FEEDING GROUPS AND SPECIES}

The majority of sampling procedures developed for forest and shade tree insects were published on defoliating insects, which is the largest group represented in the sampling database (58\%; Table 1). Forty percent of all species were classified as defoliating insects (Table 1 ). Forest and shade tree defoliators are found in five insect orders, including Lepidopetra, Hymenoptera, Coleoptera, Orthoptera (including Phasmida and Mantodea), and Diptera. Fettig et al. (2001) provided only summaries on publications representing three orders, Lepidoptera (65 publications), Hymenoptera ( 7 publications), and Coleoptera (1 publication). At least two papers are available on Orthopteran pests that did not meet the criterion for inclusion in their database (Readshaw 1965; Hodson 1972). To our knowledge, no sampling technique or sampling program has been pub-

Table 1. Summary of publications available on sampling methods for forest and shade tree insects of North America based on review of Fettig et al. (2001).

\begin{tabular}{|c|c|c|c|c|c|}
\hline Feeding group ${ }^{z}$ & Orders & $\begin{array}{l}\text { No. of } \\
\text { families }\end{array}$ & $\begin{array}{l}\text { No. of } \\
\text { species }\end{array}$ & $\begin{array}{l}\text { No. of } \\
\text { publications }\end{array}$ & $\begin{array}{l}\text { Total no. of } \\
\text { publications }\end{array}$ \\
\hline \multirow[t]{2}{*}{ Bud, shoot, and root } & Coleoptera & 2 & 4 & $10(50)^{y}$ & \multirow[t]{2}{*}{$20(16)^{x}$} \\
\hline & Lepidoptera & 1 & 6 & $10(50)$ & \\
\hline \multirow[t]{3}{*}{ Defoliating } & Coleoptera & 1 & 1 & $1(1)$ & \multirow[t]{3}{*}{$73(58)$} \\
\hline & Hymenoptera & 2 & 6 & $7(10)$ & \\
\hline & Lepidoptera & 8 & 15 & $65(89)$ & \\
\hline \multirow[t]{2}{*}{ Piercing-sucking } & Acari & 1 & 2 & $3(25)$ & \multirow[t]{2}{*}{$12(10)$} \\
\hline & Homoptera & 4 & 9 & $9(75)$ & \\
\hline \multirow[t]{2}{*}{ Seed and cone } & Diptera & 2 & 2 & $4(67)$ & \multirow[t]{2}{*}{$6(5)$} \\
\hline & Lepidoptera & 1 & 2 & $2(73)$ & \\
\hline Wood- and bark-boring & Coleoptera & 2 & 8 & $14(100)$ & $14(11)$ \\
\hline Total & 6 & $22^{\mathrm{w}}$ & 55 & 125 & 125 \\
\hline
\end{tabular}

${ }^{2}$ As defined and reported by Fettig et al. (2001).

yNumber (percentage of total number of publications within feeding group).

${ }^{\mathrm{x}}$ Number (percentage of total number of publications).

${ }^{\mathrm{w}}$ One family (Tortricidae) represented in three feeding groups. lished on a Dipteran defoliator of forest or shade trees. In general, these species are of limited importance. Among the best known is the native holly leafminer, Phytomyza iliccola Loew (Diptera: Agromyzidae), a common pest of American holly, Ilex apaca Ait., in the eastern United States (Coulson and Witter 1984).

The most commonly referenced defoliators were the gypsy moth, Lymantria dispar (L.) (Lepidoptera: Lymantriidae) (14 publications); Douglas-fir tussock moth, Orgyia pseudotsugata (McDunnough) (Lepidoptera: Lymantriidae) (11 publications); spruce budworm, Choristoneura fumiferana (Clemens) (Lepidoptera: Tortricidae) (10 publications); and western spruce budworm, C. occidentalis Freeman (8 publications) (Table 2). These four species alone accounted for 35\% of all publications in the database, and they are also the most common species represented among the five feeding groups. All are notable pests that have had a significant impact on our forested resources. Lymantria dispar was first introduced into Medford, Massachusetts, in 1869, and is now a major defoliator of hardwoods throughout eastern North America. Orgyia pseudotsugata is a major defoliator of Douglas-fir, Pseudotsuga menziesii (Mirb.) Franco, and true firs, Abies spp., throughout western North America. Choristoneura fumiferana is the most destructive defoliator of balsam fir, A. balsamea (L.) Mill., and white spruce, Picea glauca (Moench) Voss, in eastern North America. Historically, control programs for $C$. fumiferana were among the largest in the world (Sterner and Davidson 1982). Choristoneura occidentalis is an important pest of Douglas-fir; true firs; Engelmann spruce, Picea engelmannii Parry ex Engelm.; and larch, Larix occidentalis Nutt., in the western United States and Canada. Infestations in mature stands cause growth loss, top kill, and occasional tree mortality (Coulson and Witter 1984).

The second largest group represented was classified as bud, shoot, and root insects (Table 1). This group included $16 \%$ of all publications and $18 \%$ of all species reported (Table 1). Recently, research efforts have focused on the development of sampling techniques for regeneration weevils, Hylobius spp., and tip moths, Rhyacionia spp., in forest and Christmas tree plantations. The pest status of these two genera has increased with the advent of intensive forest management (Fettig and Salom 1998; Fettig et al. 2001; Asaro et al. 2003; Coyle et al. 2003). For instance, the Nantucket pine tip moth, Rhyacionia frustrana (Comstock) 
Table 2. The number of sampling publications, sequential sampling plans, and action thresholds available for forest and shade tree pests of North America. Based on review of data by Fettig et al. 2001.

\begin{tabular}{|c|c|c|c|}
\hline Species description & $\begin{array}{l}\text { No. of } \\
\text { publications }\end{array}$ & $\begin{array}{l}\text { No. of } \\
\text { sequential } \\
\text { sampling plans }\end{array}$ & $\begin{array}{l}\text { No. of action } \\
\text { thresholds }\end{array}$ \\
\hline $\begin{array}{l}\text { Bud, Shoot, and Root Insects } \\
\text { Hylobius pales (Herbst) } \\
\text { (Coleoptera: Curculionidae) }\end{array}$ & 4 & 0 & 0 \\
\hline $\begin{array}{l}\text { Hylobius radicis Buchanan } \\
\text { (Coleoptera: Curculionidae) }\end{array}$ & 2 & 0 & 1 \\
\hline $\begin{array}{l}\text { Pachylobius picivorus (Germar) } \\
\text { (Coleoptera: Curculionidae) }\end{array}$ & 3 & 0 & 0 \\
\hline $\begin{array}{l}\text { Phyllophaga spp. } \\
\text { (Coleoptera: Scarabiidae) }\end{array}$ & 1 & 1 & 1 \\
\hline $\begin{array}{l}\text { Korshceltellus gracilis (Grote) } \\
\text { (Lepidoptera: Hepialidae) }\end{array}$ & 1 & 0 & 0 \\
\hline $\begin{array}{l}\text { Eucosma sonomana Kearfott } \\
\text { (Lepidoptera: Tortricidae) }\end{array}$ & 1 & 0 & 0 \\
\hline $\begin{array}{l}\text { Rhyacionia buoliana (Denis \& Schiff.) } \\
\text { (Lepidoptera: Tortricidae) }\end{array}$ & 1 & 0 & 0 \\
\hline $\begin{array}{l}\text { Rhyacionia frustrana (Comstock) } \\
\text { (Lepidoptera: Tortricidae) }\end{array}$ & 4 & 1 & 1 \\
\hline $\begin{array}{l}\text { Rhyacionia rigidana Fernald } \\
\text { (Lepidoptera: Tortricidae) }\end{array}$ & 2 & 0 & 0 \\
\hline $\begin{array}{l}\text { Zeiraphera canadensis Mutuura \& Freeman } \\
\text { (Lepidoptera: Tortricidae) }\end{array}$ & 1 & 1 & 1 \\
\hline $\begin{array}{l}\text { Defoliating Insects } \\
\text { Pyrrhalta luteola (Müller) } \\
\text { (Coleoptera: Chrysomelidae) }\end{array}$ & 1 & 0 & 1 \\
\hline $\begin{array}{l}\text { Neodiprion lecontei (Fitch) } \\
\text { (Hymenoptera: Diprionidae) }\end{array}$ & 1 & 1 & 1 \\
\hline $\begin{array}{l}\text { Neodiprion nanulus nanulus (Schedl) } \\
\text { (Hymenoptera: Diprionidae) }\end{array}$ & 1 & 1 & 0 \\
\hline $\begin{array}{l}\text { Neodiprion sertifer (Geoffroy) } \\
\text { (Hymenoptera: Diprionidae) }\end{array}$ & 2 & 0 & 0 \\
\hline $\begin{array}{l}\text { Neodiprion swainei Middleton } \\
\text { (Hymenoptera: Diprionidae) }\end{array}$ & 1 & 1 & 0 \\
\hline $\begin{array}{l}\text { Neodiprion tsugae Middleton } \\
\text { (Hymenoptera: Diprionidae) }\end{array}$ & 1 & 1 & 0 \\
\hline $\begin{array}{l}\text { Pikonema alaskensis (Rohwer) } \\
\text { (Hymenoptera: Tenthredinidae) }\end{array}$ & 1 & 0 & 0 \\
\hline $\begin{array}{l}\text { Coleophora laricella (Hübner) } \\
\text { (Lepidoptera: Coleophoridae) }\end{array}$ & 1 & 0 & 0 \\
\hline $\begin{array}{ll}\text { Coleotechnites } & \text { milleri (Busck) } \\
\text { (Lepidoptera: } & \text { Gelechiidae) }\end{array}$ & 2 & 2 & 0 \\
\hline $\begin{array}{l}\text { Lambdina fiscellaria fiscellaria (Guenée) } \\
\text { (Lepidoptera: Geometridae) }\end{array}$ & 2 & 1 & 0 \\
\hline $\begin{array}{l}\text { Lambdina fiscellaria lugubrosa (Hulst) } \\
\text { (Lepidoptera: Geometridae) }\end{array}$ & 3 & 0 & 0 \\
\hline
\end{tabular}


Table 2. continued

\begin{tabular}{|c|c|c|c|}
\hline Species description & $\begin{array}{l}\text { No. of } \\
\text { publications }\end{array}$ & $\begin{array}{l}\text { No. of } \\
\text { sequential } \\
\text { sampling plans }\end{array}$ & $\begin{array}{l}\text { No. of action } \\
\text { thresholds }\end{array}$ \\
\hline $\begin{array}{l}\text { Operophtera bruceata (Hulst) } \\
\text { (Lepidoptera: Geometridae) }\end{array}$ & 1 & 0 & 0 \\
\hline $\begin{array}{l}\text { Malacosoma disstria Hübner } \\
\text { (Lepidoptera: } \quad \text { Lasiocampidae) }\end{array}$ & 3 & 2 & 0 \\
\hline $\begin{array}{l}\text { Lymantria dispar (Linnaeus) } \\
\text { (Lepidoptera: Lymantriidae) }\end{array}$ & 14 & 3 & 4 \\
\hline $\begin{array}{l}\text { Orgyia pseudotsugata (McDunnough) } \\
\text { (Lepidoptera: Lymantriidae) }\end{array}$ & 11 & 5 & 1 \\
\hline $\begin{array}{l}\text { Heterocampa guttivitta (Walker) } \\
\text { (Lepidoptera: Notodontidae) }\end{array}$ & 1 & 1 & 0 \\
\hline $\begin{array}{l}\text { Anisota senatoria (J.E. Smith) } \\
\text { (Lepidoptera: Saturniidae) }\end{array}$ & 2 & 0 & 1 \\
\hline $\begin{array}{l}\text { Coloradia pandora Blake } \\
\text { (Lepidoptera: Saturniidae) }\end{array}$ & 1 & 0 & 0 \\
\hline $\begin{array}{l}\text { Choristoneura biennis Freeman } \\
\text { (Lepidoptera: Tortricidae) }\end{array}$ & 1 & 0 & 0 \\
\hline $\begin{array}{l}\text { Choristoneura fumiferana (Clemens) } \\
\text { (Lepidoptera: Tortricidae) }\end{array}$ & 10 & 5 & 0 \\
\hline $\begin{array}{l}\text { Choristoneura occidentalis Freeman } \\
\text { (Lepidoptera: Tortricidae) }\end{array}$ & 8 & 2 & 0 \\
\hline $\begin{array}{l}\text { Choristoneura pinus Freeman } \\
\text { (Lepidoptera: Tortricidae) }\end{array}$ & 5 & 0 & 0 \\
\hline $\begin{array}{l}\text { Piercing-Sucking Insects and Mites } \\
\text { Nalepella tsugifolia Keifer } \\
\text { (Acari: Tetranychidae) }\end{array}$ & 1 & 0 & 1 \\
\hline $\begin{array}{l}\text { Oligonychus ununguis (Jacobi) } \\
\text { (Acari: Tetranychidae) }\end{array}$ & 2 & 2 & 1 \\
\hline $\begin{array}{l}\text { Adelges abietis (Linnaeus) } \\
\text { (Homoptera: Adelgidae) }\end{array}$ & 1 & 0 & 0 \\
\hline $\begin{array}{l}\text { Adelges cooleyi (Gillette) } \\
\text { (Homoptera: Adelgidae) }\end{array}$ & 1 & 0 & 0 \\
\hline $\begin{array}{l}\text { Adelges picea (Ratzeburg) } \\
\text { (Homoptera: Adelgidae) }\end{array}$ & 1 & 0 & 0 \\
\hline $\begin{array}{l}\text { Pineus pinifolia (Fitch) } \\
\text { (Homoptera: Adelgidae) }\end{array}$ & 1 & 1 & 0 \\
\hline $\begin{array}{l}\text { Drepanaphis acerifoliae (Thomas) } \\
\text { (Homoptera: Aphididae) }\end{array}$ & 1 & 0 & 1 \\
\hline $\begin{array}{l}\text { Mindarus abietinus Koch } \\
\text { (Homoptera: Aphididae) }\end{array}$ & 1 & 0 & 1 \\
\hline $\begin{array}{l}\text { Aphrophora saratogensis (Fitch) } \\
\text { (Homoptera: Cercopidae) }\end{array}$ & 1 & 0 & 1 \\
\hline $\begin{array}{l}\text { Cinaria laricifex (Fitch) } \\
\text { (Homoptera: Cercopidae) }\end{array}$ & 1 & 1 & 0 \\
\hline $\begin{array}{l}\text { Coccus pseudomagnoliarum (Kuwana) } \\
\text { (Homoptera: Coccidae) }\end{array}$ & 1 & 0 & 1 \\
\hline
\end{tabular}


Table 2. continued

\begin{tabular}{|c|c|c|c|}
\hline Species description & $\begin{array}{l}\text { No. of } \\
\text { publications }\end{array}$ & $\begin{array}{l}\text { No. of } \\
\text { sequential } \\
\text { sampling plans }\end{array}$ & $\begin{array}{l}\text { No. of action } \\
\text { thresholds }\end{array}$ \\
\hline $\begin{array}{l}\text { Seed and Cone Insects } \\
\text { Strobilomyia neanthracina (Czerny) } \\
\text { (Diptera: Anthomyiidae) }\end{array}$ & 2 & 1 & 1 \\
\hline $\begin{array}{l}\text { Contarinia oregonensis Foote } \\
\text { (Diptera: Cecidomyiidae) }\end{array}$ & 2 & 1 & 1 \\
\hline $\begin{array}{l}\text { Barbara colfaxiana (Kearfott) } \\
\text { (Lepidoptera: Tortricidae) }\end{array}$ & 1 & 1 & 1 \\
\hline $\begin{array}{l}\text { Cydia strobilella (Linnaeus) } \\
\text { (Lepidoptera: Tortricidae) }\end{array}$ & 1 & 0 & 1 \\
\hline $\begin{array}{l}\text { Wood- and Bark-Boring Insects } \\
\text { Monochamus notatus (Drury) } \\
\text { (Coleoptera: Cerambycidae) }\end{array}$ & 1 & 1 & 1 \\
\hline $\begin{array}{l}\text { Monochamus oregonensis (LeConte) } \\
\text { (Coleoptera: Cerambycidae) }\end{array}$ & 1 & 1 & 1 \\
\hline $\begin{array}{l}\text { Dendroctonus brevicomis LeConte } \\
\text { (Coleoptera: Scolytidae) }\end{array}$ & 1 & 0 & 0 \\
\hline $\begin{array}{l}\text { Dendroctonus frontalis Zimmermann } \\
\text { (Coleoptera: Scolytidae) }\end{array}$ & 6 & 0 & 1 \\
\hline $\begin{array}{l}\text { Dendroctonus ponderosae Hopkins } \\
\text { (Coleoptera: Scolytidae) }\end{array}$ & 2 & 1 & 0 \\
\hline $\begin{array}{l}\text { Dendroctonus rufipennis Kirby } \\
\text { (Coleoptera: Scolytidae) }\end{array}$ & 1 & 1 & 1 \\
\hline $\begin{array}{l}\text { Scolytus ventralis LeConte } \\
\text { (Coleoptera: Scolytidae) }\end{array}$ & 1 & 0 & 0 \\
\hline $\begin{array}{l}\text { Trypodendron lineatum (Olivier) } \\
\text { (Coleoptera: Scolytidae) }\end{array}$ & 1 & 0 & 0 \\
\hline
\end{tabular}

(Lepidoptera: Tortricidae), caused a growth loss of US\$366,590 $(10,474$ cords) in Florida in 1999. It is likely that losses in other states where the preferred host loblolly pine, P. taeda L., is grown more extensively would grossly exceed this figure (Fettig and Berisford 2002). Such figures are not available regarding the impact to the Christmas tree industry but are thought to be significant (Asaro et al. 2003).

Wood- and bark-boring insects accounted for $11 \%$ of all publications and included reviews on sampling techniques for the southern pine beetle, Dendroctonus frontalis

Zimmerman. The southern pine beetle is the most important forest pest in the southern United States. In 2000, D. frontalis impacted 4.9 million ha (12.1 million ac) of pine forest, resulting in a loss of US $\$ 100.4$ million (USDA-FS 2000). Much effort has gone into developing sampling methods to describe the population dynamics of this species (Coulson 1979, 1980), but few are useful for IPM purposes. This species was the fifth ( 6 publications) most frequently referenced species in the database (Table 2).

The piercing-sucking feeding group accounted for $10 \%$ of all publications, while seed and cone insects accounted for only 5\% (Table 1). Although seed and cone insects are represented in seven orders, relatively few species are of importance in modern seed orchards. The most notable pests are routinely managed with insecticides on a calendar basis. Unfortunately, too many managers rely on calendar sprays and other nonjudicious uses of insecticides without knowledge of population trends, which often leads to secondary pest outbreaks (Cameron 1981).

\section{RELATIVE ABUNDANCE OF ORDERS AND FAMILIES}

The most common order represented was Lepidoptera, which accounted for $62 \%$ of all publications (Table 1 ). The vast majority of these publications were in the defoliating insect group. The order was absent from the piercing-sucking (by definition) and wood- and bark-boring feeding groups. There are notable Lepidopteran wood-boring insects, such as the carpenterworm, Prionoxystus robiniae (Peck) (Lepidoptera: Cossidae), but to our knowledge, sampling programs have not been developed for these species. Coleoptera was a distant second, accounting for $20 \%$ of all publications in the database (Table 1). 
Tortricidae (Lepidoptera) was the most common family among species reported by Fettig et al. (2001). This family was unique in that representatives were present in three feeding groups (Table 2). Thirty percent of all publications included sampling methods or programs relevant to tortricid species. Lymantriidae (Lepidoptera) was a distant second and accounted for $20 \%$ of publications. Only two species, $L$. dispar and O. pseudotsugata, were represented. However, both are notable defoliators that receive near-continuous research attention in both urban and forested environments.

\section{RELATIVE ABUNDANCE OF HOSTS}

Eighty-one percent of summaries referenced a conifer as the primary host. Pinus (30\%), Picea (19\%), and Abies (15\%) were the most commonly reported genera. Four of the most commonly referenced species are exclusively pests of conifers, including O. pseudotsugata, C. fumiferana, C. occidentalis, and D. frontalis (Table 2). Although L. dispar is known to feed on conifers, this phenomenon is rare and often occurs only in the absence of preferred hosts (Coulson and Witter 1984). Among hardwoods, the most common hosts were Quercus spp.

\section{RELATIVE ABUNDANCE OF FOREST AND SHADE TREE PESTS}

Ninety-two percent of the species reported were predominately forest pests (Table 2). The substantial lack of publications on shade tree insects is surprising. Shade trees, such as those located in residential, recreational, or administrative sites, are particularly susceptible to insect attack as a result of increased amounts of stress associated with drought, soil compaction, mechanical injury, or vandalism. Additionally, the effectiveness of biological controls is reduced in these systems (Coulson and Witter 1984). The value of these trees is also much higher than their forest counterparts (McPherson et al. 1999). For example, Nowak et al. (2001) estimated the maximum potential impact of the Asian longhorned beetle, Anoplophora glabripennis (Coleoptera: Cerambycidae), to urban forests at US $\$ 669$ billion. Individual estimates ranged from US $\$ 72$ million to US $\$ 2.3$ billion per city. The urban forest is a large and currently expanding area that provides numerous benefits to its residents (Dwyer et al. 2003).

The need for sampling programs of shade tree insects is paramount. The system naturally lends itself to the development and implementation of such tools because of the "market values" of the crop, the increased susceptibility of the hosts, and their relatively isolated distribution within the landscape. Unfortunately, at present, such programs are lacking, and communities are most frequently forced to rely on crude judgments for control decision-making. A notable exception is the recent development and implementation of citywide monitoring programs for the elm leaf beetle, Xanthogaleruca luteola (Müller), in California (Lawson and Dahlsten 2003). This program resulted in a dramatic reduction in insecticide use at a considerable cost saving (Lawson and Dahlsten 2003) and is a prime example of the importance of developing such tools and the benefits that can be realized by their application to the urban forest.

\section{RELATIVE ABUNDANCE OF SEQUENTIAL OR BINOMIAL SAMPLING PLANS AND ACTION THRESHOLDS}

In our analysis, we tallied the total number of sequential sampling plans, action thresholds, and density-damage relationships (that did not explicitly specify an action threshold) in each feeding group because of their importance in control decision-making. In several publications, an action threshold (or economic impact level, EIP) was not specified. In these cases, we used the high-density estimates as an action threshold when available.

\section{Sequential and Binomial Sampling Plans} Sequential sampling plans were reported for 30\%, 55\%, $27 \%, 75 \%$, and $50 \%$ of the species in each feeding group, respectively (Table 2). More than $45 \%$ of all species have sequential sampling plans available (Table 2). Of species classified as at least moderately important in the United States, 26\% have sequential sampling plans. Unfortunately, to our knowledge, few receive much attention by practitioners. Of the five species for which the majority of sampling programs have been developed, only $D$. frontalis is without a sequential sampling plan (Table 2). Sampling for this forest pest has focused on area-wide trapping surveys to forecast changes in population trends (Billings 1988). It has been difficult to develop a useful and easy-to-implement sampling procedure for $D$. frontalis, and other bark beetles because they remain hidden beneath the bark for most of the life cycle (Coulson and Witter 1984).

\section{Action Thresholds and Other Density-Damage Relationships}

Action thresholds are available for $42 \%$ of the species reported and for all seed and cone insects referenced. Insects that infest reproductive structures are often considered among the most significant forest pests (Coulson and Witter 1984). Prior to the early 1960s, these species were of relatively little importance to forestry. With the advent of extensive seed orchards to produce genetically superior seeds, interests in managing insect associated losses increased. To that end, all sampling publications were published after 1980. Action thresholds were provided for 55\% of piercing-sucking pests (Table 2). These pests mainly degrade the aesthetic quality of ornamental and Christmas trees. Enumerative sampling is often required for control decision-making in place of binomial or sequential sampling plans (Sidebottom 1995). A density-damage relationship is available for an additional $12 \%$ of the species reported by 
Fettig et al. (2001), including 9\% of forest pests of at least moderate importance in the United States and Canada (Armstrong and Ives 1995; USDA-FS 1998, 1999, 2000).

\section{IPM IMPLEMENTATION}

Integrated Pest Management (IPM) programs attempt to reduce insect-associated losses to acceptable levels using multiple techniques that are effective, economically viable, and ecologically compatible. Sampling to determine population density or classify pest status is the cornerstone of most IPM programs. Much effort has been devoted to the development, theory, and application of sampling methods (Fettig et al. 2001). However, our research indicates that only $38 \%$ of species listed as at least moderately important in the United States and Canada currently have useful sampling programs available. Even fewer of these programs have been incorporated into well-defined IPM programs. A notable exception is the recent development of an IPM program for R. frustrana (Asaro et al. 2003). The species is a common regeneration pest of pine plantations in the southeastern United States. Larval feeding can cause shoot mortality and tree deformity, height and volume reductions, compression wood increases, and occasional tree mortality (Asaro et al. 2003). The complex of pest, host, and system naturally lends itself to IPM practices.

The IPM program for $R$. frustrana includes six distinct components. Initially, host species (1) and plantation age (2) are used for basic hazard rating (3) of the infested stand (Hood et al. 1986). High hazard stands are recommended for further monitoring via pheromone-baited traps to estimate damage levels (4) (Asaro and Berisford 2001). If high damage is predicted, chemical control may be warranted to avoid economically significant growth losses, particularly on sites of medium to high quality (5). Insecticide spray timing models and schedules are reported that allow increased efficacy and reduced application frequency over conventional calendar sprays (Fettig and Berisford 1999, 2002; Fettig et al. 1998, 2000a, 2000b, 2003). Finally, post-treatment evaluations (6) are recommened because continual, nonjudicious use of insecticides is not economical or environmentally sound and can lead to secondary outbreaks of scales and aphids (Asaro et al. 2003). This IPM program incorporates knowledge accumulated during 40 years of both basic and applied research. Its development is a primary example of the need for developing sampling techniques and programs that later can be integrated with control methods (Asaro et al. 2003).

A significant opportunity exists for developing similar tools to aid in control decision-making for a large number of pests (Table 2). Significant efforts should be conducted to provide tools that are useful to the resource manager, urban forester, and arborist for the major forest and shade tree pests. Current trends suggest that efforts should concen- trate on species important to the urban forest and intensively managed forest plantations.

\section{LITERATURE CITED}

Armstrong, J.A., and W.G.H. Ives. 1995. Forest Insect Pests in Canada. Ottawa, Ontario, Canada, Natural Resources Canada, Canadian Forest Service, Science and Sustainable Development Directorate.

Asaro, C., and C.W. Berisford. 2001. Predicting infestation levels of the Nantucket pine tip moth (Lepidoptera: Tortricidae) using pheromone traps. Environ. Entomol. 30:776-784

Asaro, C., C.J. Fettig, K.W. McCravy, J.T. Nowak, and C.W. Berisford. 2003. The Nantucket pine tip moth: A literature review with management implications. J. Entomol. Sci. 38:1-40.

Barbosa, P., and M.R. Wagner. 1989. Introduction to Forest and Shade Tree Insects. Academic Press, San Diego, CA.

Billings, R.F. 1988. Forecasting southern pine beetle infestation trends with pheromone traps, pp 295-306. In Payne, T.L., and H. Saarenmaa (Eds.). Integrated Control of Scolytid Bark Beetles. Virginia Polytechnic Institute and State University, Blacksburg, VA.

Binns, M.R., and N.J. Bostanian. 1990. Robustness in empirically based binomial decision rules for integrated pest management. J. Econ. Entomol. 83:420-427.

Binns, M.R., and J.P. Nyrop. 1992. Sampling insect populations for the purpose of IPM decision-making. Ann. Rev. Entomol. 37:427-453.

Brewer, M.J., D.E. Legg, and J.E. Kaltenbach. 1994. Comparison of three sequential sampling plans using binomial counts to classify insect infestation with respect to decision thresholds. Environ. Entomol. 23:812-826.

Buhyoff, G.J., J.D. Wellman, and T.C. Daniel. 1982.

Predicting scenic quality for mountain pine beetle and western spruce budworm damaged forest vistas. For. Sci. 28:827-838.

Cameron, R.S. 1981. Towards Integrated Pest Management in Southern Pine Seed Orchards, with Emphasis on the Biology of Tetyra bipunctata (Hemiptera: Pentatomidae) and the Pheromone of Dioryctria clariorlas (Lepidoptera: Pyralidae). Texas Forest Service Publication 126.

Coffelt, M.A., and P.B. Schultz. 1990. Development of an aesthetic injury level to decrease pesticide use against orangestriped oakworm (Lepidoptera: Saturniidae) in an urban pest management project. J. Econ. Entomol. 83:2044-2049.

Coulson, R.N. 1979. Population dynamics of bark beetles. Annu. Rev. Entomol. 24:417-447.

1980. Population dynamics. In Thatcher, R.C., J.L. Searcy, J.E. Costner, and G.D. Hertel (Eds.). The Southern Pine Beetle. General Technical Bulletin 1631. USDA Forest Service, Washington, DC. 267 pp. 
Coulson, R.N., and J.A. Witter. 1984. Forest Entomology: ecology and Management. John Wiley \& Sons, New York, NY. 669 pp.

Coyle, D.R., J.T. Nowak, and C.J. Fettig. 2003. Irrigation and fertilization effects on Nantucket pine tip moth (Lepidoptera: Tortricidae) damage in an intensively managed pine plantation. J. Entomol. Sci. 38:621-630.

Dent, D. 1991. Insect Pest Management. CAB International, Wallingford, UK.

Dwyer, J.F., D.J. Nowak, and M.H. Noble. 2003. Sustaining urban forests. J. Arboric. 29:49-55.

Fettig, C.J., and S.M. Salom. 1998. Comparisons of two trapping methods for Hylobius pales (Coleoptera: Curculionidae) in Virginia. Environ. Entomol. 27:572577.

Fettig, C.J., and C.W. Berisford. 1999. Nantucket pine tip moth phenology in eastern North Carolina and Virginia: Implications for effective timing of insecticide applications. South. J. Appl. For. 23:30-38.

- 2002. Use of historical temperature data for timing insecticide applications of the Nantucket pine tip moth (Lepidoptera: Tortricidae): Evaluation of damage and volume increment. J. Agric. For. Entomol. 4:1-5.

Fettig, C.J., C.W. Berisford, and M.J. Dalusky. 1998. Revision of a timing model for chemical control of the Nantucket pine tip moth (Lepidoptera: Tortricidae) in the southeastern coastal plain. J. Entomol. Sci. 33:336-342.

Fettig, C.J., M.J. Dalusky, and C.W. Berisford. 2000a. Nantucket Pine Tip Moth Phenology and Timing of Insecticide Spray Applications in Seven Southeastern States. Research Paper SRS-18. USDA Forest Service Southern Research Station, Asheville, NC. 21pp.

Fettig, C.J., K.W. McCravy, and C.W. Berisford. 2000b. Effects of Nantucket pine tip moth insecticide spray schedules on loblolly pine seedlings. South. J. Appl. For. 24:106-111.

Fettig, C.J., J.G. Fidgen, Q.C. McClellan, and S.M. Salom. 2001. Sampling Methods for Forest and Shade Tree Insects of North America. FHTET-2001-01. USDA Forest Service, Morgantown, WV. 273 pp.

Fettig, C.J., J.T. Nowak, D.M. Grosman, and C.W. Berisford. 2003. Nantucket Pine Tip Moth Phenology and Timing of Insecticide Applications in the Western Gulf Region. Research Paper SRS-32. USDA Forest Service Southern Research Station, Asheville, NC. 13 pp.

Fowler, G.W., and A.M. Lynch. 1987. Sampling plans in insect pest management based on Wald's sequential probability ratio test. Environ. Entomol. 16:345-354.

Fox, G., J. Beke, T. Hopkin, and D. McKenney. 1997. A framework for the use of economic thresholds in forest pest management. For. Chron. 73:331-339.
Hodson, A.C. 1972. Distribution and abundance of the northern walkingstick, Diapheromera femorata. Ann. Entomol. Soc. Am. 65:876-882.

Hood, W.M., R.L. Hedden, and C.W. Berisford. 1986. Hazard rating forest sites for pine tip moth, Rhyacionia spp., in the upper Piedmont plateau. For. Sci. 34:1083-1093.

Kuno, E. 1991. Sampling and analysis of insect populations. Annu. Rev. Entomol. 36:285-304.

Lawson, A.B., and D.L. Dahlsten. 2003. Implementation of a citywide monitoring program to base treatment decisions on elm leaf beetle abundance. J. Arboric. 29:34-41.

Legg, D.E., R.M. Nowierski, M.G. Feng, F.B. Peairs, G.L. Hein, L.R. Elberson, and J.B. Johnson. 1994. Binomial sequential sampling plans and decisions support algorithms for managing the Russian wheat aphid (Homoptera: Aphididae) in small grains. J. Econ. Entomol. 87:1513-1533.

Liebhold, A., K. Thorpe, J. Ghent, and D.B. Lyons. 1994. Gypsy Moth Egg Mass Sampling for Decision-Making: A User's Guide. NA-TP-04-94. USDA Forest Service, Morgantown, WV.

McPherson, E.G., J.R. Simpson, P.J. Peper, and Q. Xiao. 1999. Benefit-cost analysis of Modesto's municipal urban forest. J. Arboric. 25:235-248.

Morris, R.F. 1955. The development of sampling techniques for forest insect defoliators with particular reference to the spruce budworm. Can. J. Zool. 33:225.

Nowak, D.J., J. Pasek, R.A. Sequeira, D.R. Crane, and V.C. Masto. 2001. Potential effects of Anoplophora glabripennis (Coleoptera: Cerambycidae) on urban trees in the United States. J. Econ. Entomol. 94:116-122.

Nyrop, J.P., and M.R. Binns. 1992. Quantitative Methods for Designing and Analyzing Sampling Programs for Use in Pest Management. CRC Press, Boca Raton, FL.

Pedigo, L.P. 1989. Entomology and Pest Management. Macmillan, New York, NY. 646 pp.

- 1994. Introduction to sampling arthropod populations. In Pedigo, L.P., and G.D. Buntin (Eds.). Handbook of Sampling Methods for Arthropods in Agriculture. CRC Press, Boca Raton, FL.

Pedigo, L.P., and G.D. Buntin. 1994. Handbook of Sampling Methods for Arthropods in Agriculture. CRC Press, Boca Raton, FL.

Pedigo, L.P., S.H. Hutchins, and L.G. Higley. 1986. Economic injury levels in theory and practice. Annu. Rev. Entomol. 31:341-368.

Power, J.M., M. Stone, and T.C. Daniel. 2001. Proceedings: Decision Support-2001, Volume I. 17th Annual Geographic Information Seminar and the Resource Technology Symposium. September 12-16, 1994, Toronto, ON. 
Raupp, M.J., C.S. Koehler, and J.A. Davidson. 1992. Advances in implementing integrated pest management for woody landscape plants. Annu. Rev. Entomol. 37:561-585.

Rawat, J.K., K.L. Belli, S.M. Smith, and J.C. Nautiyal. 1987. A pest and timber management model: Jack pine budworm and jack pine. Can. J. Agric. Econ. 35:441-461.

Readshaw, J.L. 1965. A theory of phasmatid outbreak release. Aust. J. Zool. 13:475-490.

Rieske, L.K., and K.F. Raffa. 1993. Potential use of baited pitfall traps in monitoring pine root weevil, Hylobius pales, Pachylobius picivorus, and Hylobius radicis (Coleoptera: Curculionidae) populations and infestation levels. J. Econ. Entomol. 86:475-485.

Royama, T. 1992. Analytical Population Dynamics. Chapman $\&$ Hall, Hong Kong, China.

Sidebottom, J.R. 1995. Rust Mites in Christmas Trees. CTN029. North Carolina State University Cooperative Extension Service, Raleigh, NC.

Southwood, T.R.E. 1978. Ecological Methods with Particular Reference to the Study of Insects Populations. Chapman $\&$ Hall, New York, NY.

Sterner, T.E., and A.G. Davidson. 1982. Forest Insect and Disease Conditions in Canada, 1981. Canadian Forest Service, Ottawa, ON.

Strickland, A.H. 1961. Sampling crop pests and their hosts. Annu. Rev. Entomol. 6:201-220.

United States Department of Agriculture, Forest Service (USDA-FS). 1998. Forest Insect and Disease Conditions in the United States, 1998. USDA Forest Service, Forest Health Protection, Annual Report. www.fs.fed.us/ foresthealth/annual_i_d_conditions/.
1999. Forest Insect and Disease Conditions in the United States, 1999. USDA Forest Service, Forest Health Protection, Annual Report. www.fs.fed.us/foresthealth/ annual_i_d_conditions/.

2000. Forest Insect and Disease Conditions in the United States, 2000. USDA Forest Service, Forest Health Protection, Annual Report. www.fs.fed.us/foresthealth/ annual_i_d_conditions/.

Waters, W.E. 1955. Sequential sampling in forest insect surveys. For. Sci. 1: 68-79.

Acknowledgments. We are grateful to S. Clarke, C. Dabney, S. Liebhold (USDA Forest Service), and C. Broeckling (Virginia Tech University) for reviewing earlier versions of this manuscript. This work was supported by the USDA Forest Service, Forest Health Technology and Enterprise Team (FHTET), the International Society of Arboriculture Research Trust, and by a CALS and 229 Distance Education Grant from Virginia Tech to SMS.

This article was written and prepared by U.S. Government employees on official time and it is, therefore, in the public domain and not subject to copyright.

${ }^{1 *}$ Principal Research Entomologist

Pacific Southwest Research Station

USDA Forest Service

1107 Kennedy Place, Suite 8

Davis, CA 95616, U.S.

${ }^{2}$ Research Associate

${ }^{3}$ Associate Professor

Department of Entomology

Virginia Polytechnic Institute and State University

Blacksburg, VA 24061, U.S.

"Corresponding author. 
Résumé. Les programmes de gestion intégrés des insectes et des maladies ont pour objectif de réduire les pertes associés aux insectes à des degrés acceptables au moyen de multiples techniques qui sont efficaces, économiquement viables et écologiquement compatibles. Léchantillonnage est la pierre angulaire de tout programme de gestion intégrée des insectes et des maladies. Des efforts significatifs ont donc été dévolus au développement, à la théorie et à l'application de méthodes d'échantillonnage.

Relativement peu de programmes de gestion intégré des insectes et des maladies existent pour gérer les problèmes de parasites sur les arbres forestiers et ornementaux, et ce en dépit de la disponibilité de procédures d'échantillonnage qui sont potentiellement utiles dans le contrôle de la prise de décision. La majorité de ces procédures d'échantillonnage sont produites en relation avec des insectes défoliateurs ( $58 \%$ de toutes celles produites). Les défoliateurs les plus référencés sont la spongieuse (Lymantra dispar), la chenille du sapin-de-douglas (Orgyia pseudotsugata), la tordeuse des bourgeons de l'épinette (Choristoneura fumiferana) et la tordeuse des bourgeons de l'épinette de l'Ouest (C. occidentalis). Ces quatre espèces seulement comptent pour plus de 35\% de toutes les publications traitant des méthodes d'échantillonnage relativement aux programmes de gestion d'insectes et de maladies. Le second plus important groupe concerne les insectes des bourgeons, des pousses et des racines (18\%), suivi de près par celui des insectes perceurs du bois et de l'écorce (11\%). Le groupe des insectes perforateurs et suceurs (10\%), ainsi que ceux du groupe des semences et des cônes (5\%), ne comportent que peu de procédures d'échantillonnage. Quatre-vingt-douze pourcents des espèces représentées sont, de manière prédominante, des espèces forestières de l'ordre des lépidoptères et de la famille des tortricidacées. Une opportunité significative existe de développer des outils similaires pour aider au contrôle dans la prise de décision pour un nombre très important d'autres parasites. Les tendances actuelles suggèrent que les efforts devraient être concentrés sur les espèces importantes pour la forêt urbaine et dans les plantations forestières intensives.

Zusammenfassung. Programme zum Integrierten Pflanzenschutz versuchen, die Verluste durch Insektenbefall auf akzeptable Level zu reduzieren, indem sie verschiedene Techniken, die ökonomisch effektiv und wertvoll, sowie ökologisch verträglich sind, zu nutzen. Die Probennahme ist ein Kernstück jedes IPMProgramms und es hat bislang einen deutlichen Erfolg in der Entwicklung, Theorie und Applikation von Probennahmemethoden gegeben. Relativ wenige IPM-Programme existieren für Forst und Schattenbäume, bis auf die Möglichkeit der Probennahme, die für die Kontrollentscheidungen nützlich sein können. Die meisten dieser Probennahmemethoden sind für entlaubende Insekten publiziert (58\% aller Publ.). Die meistgenannten Entlauber sind die Lymantria dispar (L.), Orgyia pseudotsugata (McDunnough), Choristoneura fumiferana (Clemens) und die C. occidentalis Freeman. Diese vier Arten allein sind Gegenstand von 35\% der genannten Publikationen von IPM-Programmen. Die zweitgrößte Gruppe stellen die Knospen-, Trieb- und Wurzelschädlinge dar (16\%) gefolgt von den Holz- und Rindebohrenden Insekten (11\%). Die stechend-saugenden Insekten (10\%) und die Samen und Zapfen angreifenden Insekten (5\%) haben relativ wenige Probennahmemethoden. 92\% der dargestellten Arten sind hauptsächlich Forstschädlinge aus der Gattung Lepidoptera und aus der Familie Tortricidae. Es besteht eine deutliche Möglichkeit, ähnliche Werkzeuge für die Kontrollentscheidung bei anderen Schädlingen zu entwickeln. Gegenwärtige Trends zeigen, dass die Bemühungen sich auf wichtige Schädlingsarten in der urbanen und der Intensiv-Forstwirtschaft konzentrieren sollten.

Resumen. Los programas de Manejo Integrado de Plagas (IPM) intentan reducir las pérdidas asociadas a insectos a niveles aceptables usando técnicas múltiples que son efectivas, económicamente viables y ecológicamente compatibles. El muestreo es la piedra angular de cualquier programa de IPM, y se han desarrollado esfuerzos significativos para desarrollar la teoría y la aplicación de métodos de muestreo. Existen relativamente pocos programas IPM para manejar las plagas de los bosques y árboles de sombra a pesar de la disponibilidad de procedimiento de muestreo que son potencialmente útiles para controlar la toma de decisiones. La mayoría de estos procedimientos son publicados con insectos defoliadores (58\% de todas las publicaciones). Los defoliadores más comúnmente referenciados son la mariposa gitana, Lymantria dispar (L.), el gusano del Abeto-Douglas Orgyia pseudotsugata (McDunnough), el del abeto, Choristoneura fumiferana (Clemens), y el del abeto del oeste, C. occidentalis Freeman. Estas cuatro especies responden solas por el $35 \%$ de todas las publicaciones de muestreos relevantes en los programas de IPM. El segundo gran grupo es el de los insectos de raíces y brotes (18\%), seguido de cerca por los insectos barrenadores (11\%). El grupo de los chupadores (10\%) y los insectos de conos y semillas (5\%) tienen relativamente pocos procedimientos disponibles. Noventa y dos por ciento de las especies representadas son predominantemente plagas de los bosques con el orden Lepidoptera y la familia Tortricidae más comúnmente reportados. Existe una oportunidad significativa para desarrollar herramientas similares para ayudar al control en la toma de decisiones de un gran número de otras plagas. Actualmente las tendencias sugieren que los esfuerzos deberán concentrarse en especies importantes del bosque urbano y plantaciones forestales manejadas intensivamente. 